tance, such as those now appearing on various aspects of the utilization of waste materials.

It is, however, in the matter of leading articles and critical notes that NATURE is perhaps most deeply concerned in the freedom of the Press. A rigidly controlled Press is a characteristic feature of totalitarian rule, echoing with fulsome monotony the official view. It is equally characteristic of the democratic system that officialdom is open to criticism, out of which comes further progress. This is the particular 'freedom' for which a journal such as Nature must stand; not the freedom to make malicious attacks on the policy of Government, but the freedom to make constructive criticism in order to promote the cause we all have at beart. It is a hardly won privilege, which we have used, and shall continue to use, with a keen sense of responsibility.

\title{
SCIENTIFIC METHOD IN ADMINISTRATION
}

$\mathrm{T}$ HE willingness and cheerfulness with which the whole nation has accepted the drastic restrictions now being placed on civilian supplies and the use by the Minister of Labour and National Service of the wide powers of control which he now possesses over labour and industry, are a measure of the determination of the British people to continue the struggle for freedom in the world. The magnificent response of labour to $\mathrm{Mr}$. Bevin's appeal indeed shows that the people of Great Britain have shed any lingering illusions as to the magnitude of the effort demanded of them all, but it would be unfair to place all the responsibility for this apparent change on the dramatic swiftness with which the tide of war has rolled towards our own shores since the invasion of the Low Countries and France. Part at least of the response is due to a leadership for which many had been impatiently waiting for months.

The changes and effort involved in the transference from a peace-time to a war economy have been reviewed in a number of admirable broad. sheets issued by P E P (Political and Economic Planning), notably under the titles "The Home Front" and "Industrial Man Power", and the second of these broadsheets reviewed the position up to the recent change in Government. Since then we have moved much nearer to a full war economy. It has become a matter of life and death that the habits and customs of a laisser-faire society should be abandoned, and the economic and social implications of modern warfare be fully recognized. Just as the new order gives the Minister of Labour full and drastic powers over every man and woman in the land to ensure the most effective use of the nation's resources of man. or woman-power, so the new rationing order limiting supplies to home consumers, issued by the
Board of Trade, supplies the power to check any who are still reluctant to curb their own private requirements at a time of national need.

Fully as significant, however, as the evidence that these developments afford that the Govern. ment possesses a definite economic policy and the vision and vigour to elaborate it into the detail required, is the fact that they have been gladly accepted by a nation which was indeed largely impatient for them. For that, as we have said, credit must be given to wise and imaginative leadership, alive to the necessity of education in a constructive enterprise of this magnitude. By taking the people into its confidence, the Government kindled their imagination and paved the way for the magnificent response which in due course will enable us to wrest the initiative from the enemy, and bring final success to our efforts.

Neglect of such educational work has been an important factor in the failure of the earlier evacuation schemes for school children, and there are still many fields such as rationing, the restriction of private purchases, and civil defence, in which educational work is still required. This may well be one of the directions in which the Ministry of Information may make important contributions. With such education, there must go the utmost diligence to see that the full purpose of the new efforts is not impeded by vested or private interest of any kind. Nothing can be tolerated which is liable to endanger confidence in the impartiality or integrity of our leadership; this has special significance in considering the restriction of certain forms of sport or pleasure or of the production of some types of foodstuffs or beverages.

We are none the less entitled to the conclusion that in these difficult and anxious days, we have now a Government which is in advance-even if 
only a little-of public opinion, and not far behind it in its ideas of the sacrifices and effort that must be made, and made at once. This fact and the opportunities thereby opened up constitute at least one reason for hope in a desperate situation. If our present intense effort is wisely and effectively organized, we can gain the time and opportunity, as the full power of our resources is brought into play, to deal with those many interlocked problems not merely of a war economy but also of reconstruction after the war. We have at least come within sight of leadership of a quality competent not merely to organize effectively our resources for war but also to use wisely the immense opportunities which the catastrophe of war gives us of overthrowing obstacles which have impeded the development of society in time of peace.

It is well that this question of reconstruction should remain in our minds even at this critical hour, for many of the problems with which we are now dealing urgently are vitally related to them, and it may well be that the solutions to some of our longer range war problems and those of reconstruction may be found on similar lines. The immediate problems involved in the most efficient use of our man-power have their bearing on the unemployment problem, the magnitude of which after the War may well be determined by the lines on which our labour problems are now handled. Measures affecting the mobility of labour, its training in new types of skill, the neglect or encouragement of technical education, and the care taken in regard to training in safety methods or the safeguarding of health, whether in respect of hours of work, or factory or workshop conditions such as lighting, ventilation or the like, may have as a significant influence on the morale and adaptability of the industrial population after the War as on the efficiency of our immediate war effort.

That the Ministry of Labour has taken over from the Home Office the whole administration of the factory, including the health and welfare provisions, and that the Factory Department of the Home Office is now incorporated for the duration of the War in a new department of the Ministry of Labour called the Factory and Welfare Department, are signs that concern with the short-range problems of immediate intensive production will not lead to those of a long-range policy being overlooked. Steps have also been taken, at long last, to facilitate the development of a food policy based on scientific knowledge and control ; in no other field could a scientific policy have more far- reaching and beneficial effects both after as well as during the War. The building industry and the shipping industry are two further examples where policy or machinery established during war-time must have far-reaching repercussions on recovery.

If there are thus signs not only of energy but also of the forward-looking mind in the leadership of the Government, there is one element in the situation which has given rise to some misgivings. In his volume "Security : Can we Retrieve It ?" published shortly before the War, Sir Arthur Salter directs attention to the desirability of strengthening the Civil Service by reinforcing its personnel, at the top with leading men in industry and science, and throughout its ranks with young men of energy and constructive ability. Sir Arthur urged that only in some such way could the present machinery of civil government become competent to deal even with the task of preparation for war, for which in some ways the Civil Servant's experience is a definite handicap to him. The importance of bringing fresh blood and new methods of training into the administrative class of the Civil Service was also emphasized by Prof. Ernest Barker in an essay in the Political Quarterly so long ago as 1936 and afterwards reproduced in "The British Civil Servant" edited by Dr. W. A. Robson.

Failure to implement such criticisms or suggestions has in the meantime led to widespread concern as to whether the Civil Service, and with it the local government service, is capable of taking the measure of its war-time task. To exert our maximum effort, it is not sufficient to change Ministers and Under-Secretaries and to deal justly with causes of Parliamentary inefficiency. The increasing extent to which under modern con. ditions the permanent Civil Service has come to control the key-points in national administration makes it essential that we should consider carefully whether, by outlook, training and technique, this machinery is competent to discharge its duties at the tempo demanded by war-time conditions.

In such an examination there is, of course, no suggestion of departure from the high traditions of integrity, capacity and devotion to duty which have given the British Civil Service its world reputation. What has to be recognized is that the Civil Service attained its position of eminence in easier and more spacious days than our own, and that the fundamental principles of lengthy examination of all proposals and minute control of expenditure, on which its work is based, operated 
formerly in a restricted field. There is now real danger that loyalty to these principles, good and sound in themselves, may be carried to a point which delays action where speed is essential to safeguard our very existence.

It is now generally recognized that the growing complexity of the task of national administration, in peace no less than in war, makes demands on the machinery for which training in precedent is not the primary qualification. Parliamentary government indeed depends for its efficiency upon the existence of a body of permanent officials, serving all Governments alike and preserving the continuity of stabilizing traditions. Nonetheless, it is essential that this permanent service should be characterized not merely by vigilance, integrity and loyalty to tradition, but also by receptivity to new ideas and flexibility of mind Absence of such receptivity and flexibility, it is argued, are seriously affecting our war effort.

This position is attributed not merely to defects in training, among which the absence of a scientific outlook may well be noted. It is attributed also to the destruction of ability in the War of 1914-18, which robbed the Civil Service of many who would now have been its natural leaders. It is attributed also to the tendency of policy in the last eight years to sap the vigour and integrity of public life, checking initiative and independence in the Civil Service, thus fostering the worst features of bureaucracy.

If the immediate needs of the hour are to be served no less than those of reconstruction and re-integration after the War, some means must be found immediately of redressing this situation, whether by bringing in fresh blood or giving real opportunity to the younger men of first-class ability who are undoubtedly to be found in the Civil Service. Besides the introduction of ability from outside and the extension of transfers or promotion, devolution of authority at the lower levels to hasten decision is no less imperative than changes in personnel. There is no room for inertia or for the leisurely methods of an earlier period. We must be prepared when necessary to take drastic action to secure competence and prompt and efficient administration; only thus can we hope to see the immense resources of good will and effort stirred up by the challenge of recent weeks directed into the channels which will best serve the national purpose. From top to bottom of the administrative machine, there must be an energy and drive no less intense than that which has led so many to sacrifice leisure bours, possessions and life itself at the nation's call. Coupled with it there must be a sense of values and a width of outlook which will ensure the weighing of all factors and the basing of decisions on facts no less scientifically or surely ascertained because they are determined at the same pressure and strain which the whole nation now endures. Scientific workers may well hope that changes in the Civil Service imposed to meet our immediate War needs may facilitate the speed of a scientific outlook which will lead to much more effective use being made of our scientific resources to all departments of the national life.

\section{TOWARDS THE NEW SYSTEMATICS}

\section{The New Systematics}

Edited by Julian Huxley. Pp. viii + 583. (Oxford : Clarendon Press; London: Oxford University Press, 1940.) 21s. net.

$\mathrm{D}^{\mathrm{R}}$ R. HUXLEY and his co-authors have succeeded in producing a book which makes most stimulating reading. In all, twenty-two authors have contributed a chapter each and, as mentioned in the foreword, British authors predominate, since it was felt that this would facilitate the co-ordination of the articles. Where Great Britain could not supply a suitable authority on some subject, authors of other nationalities were invited to write a chapter. Some idea of the ground covered may be obtained from a few of the chapter headings taken at random : A museum zoologist's view of taxonomy; Mutations and geographical variation; Ecological aspects of plant taxonomy; Problems of the origin of species; Polymorphism and taxonomy; The statistical consequences of Mendelian heredity in relation to speciation; Taxonomic species and genetic systems; The new systematics of cultivated plants; and so forth. Minor systematics have naturally received the greatest share of attention for the very good reason that it is the minor units which most urgently require attention, and also, as it happens, they are the most amenable to experimental analysis.

If the reader expects to find concrete suggestions for a radical revision of the present taxonomic 